\title{
The Psycho-Social Conditions of Asylum-Seekers from Darfur in Israel
}

\author{
VERED SLONIM-NEVO, SHIRLEY REGEV, AND YIFTACH MILLO
}

\begin{abstract}
OBJECTIVE

The study appraises the prevalence of pre-migration trauma exposure, the ability to secure basic living needs, and psychological functioning among Darfuri asylumseekers and refugees living in Israel.
\end{abstract}

\section{METHOD}

The sample included 340 adults from Darfur. Standardized measures assessing socio-psychological functioning were utilized.

\section{RESULTS}

The participants demonstrated high rates of pre-migration exposure to traumatic experiences. Thirty per cent of the participants met DSM-IV criteria PTSD, with a higher proportion for women than for men. Post-migration stressors were mentioned by the majority of the participants.

\section{CONCLUSIONS}

The State of Israel should recognize past atrocities and traumas of Darfuris who arrived in Israel. Such recognition should be offered as acceptance of their rightful access to refugee status determination. Moreover, the State of Israel needs to modify government policies and legalization facilities so that Darfuri refugees and asylum-seekers will have access to basic human needs and support services.

\section{Résumé}

\section{OBJECTIF}

Cette étude évalue la prépondérance de traumatisme prémigratoire auquel sont exposés les demandeurs d'asile et réfugiés du Darfour vivant en Israël, ainsi que leur fonctionnement psychologique, et leur capacité de se procurer les besoins vitaux de base.

\section{MÉTHODE}

L'échantillon pour l'étude était constitué de 340 adultes du Darfour. Divers aspects de leur fonctionnement sociopsychologique étaient évalués à l'aide de mesures normalisées. RÉSULTATS

Les participants ont fait preuve de niveaux élevés d'exposition prémigratoire aux expériences traumatiques: $30 \%$ des participants ont satisfait aux critères du DSM-IV pour l'ESPT, avec une proportion plus élevée chez les femmes que chez les hommes. Des facteurs de stress postmigratoire ont été évoqués par la majorité des participants.

\section{CONCLUSIONS}

L'État d'Israël devrait reconnaître les atrocités et les traumatismes antérieurs subis par les Darfouriens arrivant en Israël. Cette reconnaissance devrait se manifester par une acceptation de leur droit d'accès légitime à la Détermination du statut de réfugié. Par ailleurs, il incombe à l'État d'Israël de modifier les politiques gouvernementales ainsi que les dispositifs de légalisation afin que les réfugiés et les demandeurs d'asile du Darfour puissent accéder aux services humanitaires de base et de soutien.

S ince 2003, the war in Darfur has led to more than 300,000 Darfuris' deaths, internal displacement of two million citizens, and led 350,000 refugees to cross borders seeking protection against genocide committed by the Sudanese government and paramilitary groups, including killings, rape, and burning of villages. ${ }^{1}$ Many have fled to Egypt. However, violent acts by Egyptian police led many 
to cross the border to Israel, hoping that Israel would provide them with protection. ${ }^{2}$

The initial few hundreds of Sudanese who crossed the Egyptian border were placed under administrative detention in line with the "Entry into Israel Law."3 In 2006, their custody was prolonged under the Anti-Infiltration Lawlegislation allowing the indefinite detention of those crossing the Israeli border illegally. After a petition to Israel's Supreme Court, asylum-seekers were released. They were provided with a temporary group protection, defending them from deportation, but denying them access to refugee status determination (RSD) and the rights associated with legal residency. In 2008, the government of Israel granted 490 temporary residence visas (A5) to Darfuri asylum-seekers. This group is identified in this study as "refugees" (or as "with visa") and is entitled to public services. The other group is identified here as "asylum-seekers" (or as "without visa") and is holding a temporary protection visa (A2-5 A), which grants them only protection from deportation.

The Darfuri community in Israel consists mostly of men. They encompass the majority of the 12,825 Sudanese asylumseekers registered by the Israeli Population, Immigration and Borders Authority. 4 Many initially settled in the southern city of Eilat, where employment in the hotel industry was accessible. With the saturation of available work in Eilat, many moved to Tel Aviv, establishing their lives in the southern neighbourhoods around the central bus station, where accommodation was cheaper and humanitarian assistance was available by Israeli NGos. Regrettably, the Israeli government refuses to develop an asylum policy, while it continues to impose punitive measures intended to deter further asylum-seekers from arriving in Israel. 5 These measures included geographical restrictions, blocked access for asylum-seekers to RSD; prohibited employment; forced return of asylum-seekers from the border into Egypt; and adoption of the anti-infiltration law in 2013. The law allows the Israeli authorities to hold individuals whom they regard as "infiltrators" in detention centres without charge or trial. ${ }^{6}$ Many Darfuris were transferred to the new centre of Hollot in the Negev Desert, built for this purpose. This act was followed by an opposition of the detainees and by a protest of human-rights NGOs.7 The consistent pressures, insecurity, and increasing xenophobia led many to return to Sudan. Some have since disappeared or have been imprisoned. ${ }^{8}$ In September 2014, the Israeli High Court of Justice invalidated the anti-infiltration legislation and ordered the state to shut down Hollot and re-examine the cases of all those detained within ninety days. ${ }^{9}$ This decision was ignored by the Knesset, which in turn approved an amended law, reducing detention at Hollot to twenty months. ${ }^{10}$ Apparently, new attempts by the Israeli government to keep asylum-seekers in detention centres are expected, as well as struggle to release these persons and provide them with basic human rights. In addition, Israel's Immigration Authority has been promoting a policy of "voluntary" return/deportation, which provides an alternative to detention, offering $\$ 3,500$ and a one-way ticket to Sudan, Eritrea, Uganda, or Rwanda.

In this article, we describe the refugees' experiences in Israel, their psychosocial functioning, and their quality of life in order to shed light on their plight. The study was conducted prior to the decision to detain asylum seekers in Hollot. Thus, our findings do not reflect the current experience of the Darfuris who are afraid of incarceration or have already been transferred to Hollot.

\section{Four Stages in the Refugee Experience}

Four stages in the lives of refugees are often described in the literature. Our study relates to them.

First stage, the pre-migration period: an extended period characterized by economic difficulties, social problems, political oppression, extreme physical and emotional suffering, and long periods of hiding and escaping from armed forces. The main motivation to escape is the fear of being attacked, rape, torture, and ethnic cleansing. ${ }^{11}$

Second stage, the escape: the experience of leaving home, family, and friends; refugees experience dangers on their escape route, including torture; women report sexual attacks. ${ }^{12}$

Third stage, temporary settlement or request for asylum: extended stay in refugee camps, detention centres, or urban centres in host countries. Although the refugees feel physically protected, the processes of obtaining legal recognition and of securing reunification with their families often lead to extreme anxiety; fears of deportation lead to even greater anxiety and social marginalization. ${ }^{13}$

Fourth stage, resettlement, local integration, or return to country of origin. Refugees often struggle with uncertainty and find it difficult to reorganize themselves at all levels. Some manage to become official refugees in their new countries with a right to permanent settlement. Settlement, however, often creates a need to struggle with xenophobia, racialism, unemployment, and cultural conflicts. The challenges of securing basic needs spill over to a struggle for self-identity. ${ }^{14}$

\section{Theoretical Perspective}

Forced migrants go through a process of adapting to the new environment. In Bronfenbrenner's ecological systems theory, ${ }^{15}$ the outcomes of this developmental process depend on the interaction between the individual and his or her environment. Thus, in order to understand how asylum seekers adjust, we ought to examine both individual 
and environmental characteristics. The theory presents 4 systems that affect individuals' development: (1) the microsystem-immediate contexts in which the individual participates directly (e.g., interactions among asylum-seekers' family members); (2) the meso-system-interconnections among the micro-systems (e.g., interactions between asylum-seekers and local institutions such as hospitals, and immigration authorities); (3) the exo-system-contexts that are not experienced directly by an individual but may influence his or her development (e.g., problems in the workplace); and (4) the macro-system - contexts that reflect the broad social, political, and ideological norms of the culture in which the individual lives (e.g., the political situation in the host country).

The variables in this study cover all 4 systems that affect participants' psychosocial well-being. For example, language proficiency, family relations, and psychological well-being are all part of the micro-system; perceived discrimination and interaction with health services may be considered part of the meso-system; employment and living difficulties may be part of the exo-system; and legal status and past traumatic events are part of the macro-system, both in the home country and in the host country.

\section{Methods}

Design

The study used a cross-sectional survey design. The data were collected during January-December 2012.

\section{Sample}

The sample consists of 340 participants, 64 females and 276 males, aged 18 or older, who were born in Darfur. At the time of recruiting, they lived either in the centre of the country or in the south of Israel. Participants were recruited through a contact list of Darfuri refugees who are members in an organization called "The Sons of Darfur." The list served as an initial sampling frame from which names were drawn randomly. However, much of the contact information was out of date, as many of the Darfuris had changed their addresses without notification. Therefore, we recruited the participants by using snowball sampling methods, and by approaching potential participants in social gathering places. Thus, response rates cannot be established.

The majority of the respondents were males $(81 \%)$, Muslims (99\%), about 30 years of age, had not yet gained legal status (83\%), came from rural areas (59\%), had completed about 10 years of education, left Sudan about 4 years earlier, were about 2.5 years in Israel, and had spent time in an Israeli detention centre ( $85 \%$ ) (see table 1 ).
Table 1. The socio-demographic characteristics of the sample

\begin{tabular}{|c|c|c|c|c|c|}
\hline & $\begin{array}{l}\text { Male } \\
(N= \\
276)\end{array}$ & $\begin{array}{l}\text { Female } \\
(N=64)\end{array}$ & $\begin{array}{l}\text { Has a visa } \\
(N=58)\end{array}$ & $\begin{array}{l}\text { No visa } \\
(N= \\
282)\end{array}$ & $\begin{array}{l}\text { Total } \\
(N= \\
340)\end{array}$ \\
\hline Age $(M, S D)$ & $\begin{array}{l}31.2 \\
(6.2)^{* *}\end{array}$ & $\begin{array}{l}27.2 \\
(5.8)^{* *}\end{array}$ & $32.1(5.6)$ & $30.2(6.5)$ & $\begin{array}{l}30.6 \\
(6.4)\end{array}$ \\
\hline \multicolumn{6}{|l|}{ Residency in } \\
\hline \multicolumn{6}{|l|}{ Sudan } \\
\hline Urban & $43 \%$ & $34 \%$ & $46 \%$ & $40 \%$ & $41 \%$ \\
\hline Rural & $57 \%$ & $66 \%$ & $54 \%$ & $60 \%$ & $59 \%$ \\
\hline \multicolumn{6}{|l|}{ Marital status } \\
\hline Married & $30 \% * *$ & $92 \% * *$ & $43 \%$ & $42 \%$ & $42 \%$ \\
\hline Unmarried & $70 \% * *$ & $8 \% * *$ & $57 \%$ & $58 \%$ & $58 \%$ \\
\hline $\begin{array}{l}\text { Offspring } \\
\text { Has off- }\end{array}$ & \multicolumn{4}{|c|}{ Offspring } & \\
\hline $\begin{array}{l}\text { spring } \\
\text { No off- }\end{array}$ & $26 \% * *$ & $69 \% * *$ & $36 \%$ & $34 \%$ & $34 \%$ \\
\hline spring & $74 \% * *$ & $31 \% * *$ & $64 \%$ & $66 \%$ & $66 \%$ \\
\hline $\begin{array}{l}\text { Level of } \\
\text { religiosity }\end{array}$ & & & & & 3.3 \\
\hline$(M, S D)^{a}$ & $3.3(1.2)$ & $3.6(1.4)$ & $3.0(1.3)^{*}$ & $3.4(1.2)^{*}$ & $(1.2)$ \\
\hline $\begin{array}{l}\text { Years of } \\
\text { education } \\
(M, S D)\end{array}$ & $\begin{array}{l}10.1 \\
(3.9)^{*}\end{array}$ & $8.5(5.6)^{*}$ & $9.4(4.5)$ & $9.9(4.2)$ & $\begin{array}{l}9.8 \\
(4.3)\end{array}$ \\
\hline $\begin{array}{l}\text { Time since } \\
\text { departure }\end{array}$ & & & & & \\
\hline $\begin{array}{l}\text { from Sudan } \\
\text { (in years, } M, S D \text { ) }\end{array}$ & $4.4(3.5)$ & $3.7(2.8)$ & $7.4(2.8)^{* *}$ & $\begin{array}{l}3.6 \\
(3.2)^{* *}\end{array}$ & $\begin{array}{l}4.2 \\
(3.4)\end{array}$ \\
\hline $\begin{array}{l}\text { Length of stay } \\
\text { in Israel (in } \\
\text { years, } M, S D \text { ) }\end{array}$ & $2.8(1.7)$ & $2.6(1.6)$ & $4.4(1.3)^{* *}$ & $\begin{array}{l}2.4 \\
(1.5)^{* *}\end{array}$ & $\begin{array}{l}2.8 \\
(1.7)\end{array}$ \\
\hline $\begin{array}{l}\text { Locations } \\
\text { before arriv- } \\
\text { ing in Israel }\end{array}$ & & & & & \\
\hline $\begin{array}{l}\text { Egypt } \\
\text { Libya }\end{array}$ & $\begin{array}{l}74 \% \\
\text { NA }\end{array}$ & $\begin{array}{l}72 \% \\
\text { NA }\end{array}$ & $\begin{array}{l}85 \% * \\
7 \%\end{array}$ & $\begin{array}{l}71 \% * \\
6 \%\end{array}$ & $\begin{array}{l}73 \% \\
6 \%\end{array}$ \\
\hline $\begin{array}{l}\text { Stayed in } \\
\text { detention } \\
\text { centre in } \\
\text { Israel }\end{array}$ & & & & & \\
\hline $\begin{array}{l}\text { Yes } \\
\text { No }\end{array}$ & $\begin{array}{l}88 \% * * \\
12 \% * *\end{array}$ & $\begin{array}{l}72 \% * * \\
28 \% * *\end{array}$ & $\begin{array}{l}62 \% * * \\
38 \% * *\end{array}$ & $\begin{array}{l}90 \% * * \\
10 \% * *\end{array}$ & $\begin{array}{l}85 \% \\
15 \%\end{array}$ \\
\hline $\begin{array}{l}\text { Stayed in } \\
\text { detention or } \\
\text { refugee } \\
\text { centre in }\end{array}$ & & & & & \\
\hline Egypt & & & & & \\
\hline Yes & $18 \% *$ & $6 \% *$ & $45 \% * *$ & $10 \% * *$ & $16 \%$ \\
\hline No & $82 \% *$ & $94 \% *$ & $55 \% * *$ & $90 \%{ }^{* *}$ & $84 \%$ \\
\hline
\end{tabular}




\section{Data Collection}

Nine interviewers, who were themselves from Darfur, collected the data. They conducted face-to-face interviews, usually at participants' residences.

\section{Ethical Considerations}

Ethical approval for the project was provided by the research ethics committee in Ben-Gurion University and a consent form was obtained. All data collected were confidential and anonymous. The participants received a gift card worth 100 Israeli shekels as compensation for their time.

\section{Measures}

\section{Stages 1 and 2}

\section{Pre-Immigration Traumatic Events}

A modified version of the Harvard Trauma Questionnaire (HTQ) was used. ${ }^{16}$ It includes 21 traumatic events and it ranges from 1-21, with higher scores indicating more events. The internal consistency and stability correlations in this study were good (Cronbach's $\alpha=.84 ; r=.94, p<.001$ ).

\section{Stage 3}

\section{Daily Lives in Israel}

Language proficiency in Hebrew. We used a self-report 4-item questionnaire regarding the level of understanding, speaking, reading, and writing in Hebrew. The scale ranges from 1 to 4 , with higher scores indicating greater proficiency. The internal consistency and stability correlations in this study were good (Cronbach's $\alpha=.88 ; r=.69, p<.001$ ).

Living conditions. Difficulties in living conditions were measured via a 24 -item scale adapted from the Post-Migration Living Difficulty Questionnaire (PMLD). ${ }^{17}$ PMLD ranges from 1 to 24 , with higher scores indicating more problems. The internal consistency of this scale in this study was high $(\alpha=.91)$ but it was not stable across time $(r=.35, n s)$.

Perceived discrimination. The scale consists of 5 items asking whether the respondent had experienced being disadvantaged, compared to native Israelis, at work, in the neighbourhood, when shopping, in government offices, and in bars or restaurants. The scale ranges from 1 to 4 , with higher scores reflecting a higher level of discrimination. The internal reliability of the scale in this study was high $(\alpha=.91)$ and the consistency across time was acceptable $(r=.58, p<.01)$.

\section{Psychological Functioning}

Quality of Life The World Health Organization Quality of Life: Brief Version (WHOQOL-BREF) ${ }^{18}$ is a 26 -item self-report scale that measures 4 domains of quality of life in the last 2 weeks:
(1) physical health (e.g., energy and fatigue), (2) psychological health (e.g., self-esteem), (3) social relationships (e.g., social support), and (4) environment (e.g., transportation). Participants answered on a 5-point scale, ranging from 1 to 5 . The score for each domain is calculated as the mean score of items within each domain multiplied by 4 , to make domain scores comparable with the full version of the questionnaire (i.e., WHOQOL-100). Hence, domain scores range from 4 to 20 . In this study, internal consistency and stability across time were: physical health $(\alpha=.84 ; r=.73, p<.001)$, psychological health $(\alpha=.74 ; r=.46, p<.05)$, social relationships $(\alpha=.68 ; r=.77$, $p<.001)$, and environment $(\alpha=.71 ; r=.26, n s)$.

PTSD. The PTSD Checklist-Civilian version (PCL-C) ${ }^{19}$ assesses the occurrence and severity of $D S M-I V$ symptoms of PTSD in civilian populations. Respondents are asked to rate the degree to which 17 problems had bothered them in the previous month on a scale from o to 5 (a rating of 3 or more indicated endorsement of that symptom). Individuals received a PTSD diagnosis if they endorsed one or more items from Cluster B (re-experiencing), three or more items from Cluster C (avoidance and numbing), and two or more items from Cluster D (increased arousal). In this study, the scale attained high internal reliability and for the total score $(\alpha=.94)$ and for items in Cluster B $(\alpha=.89)$, Cluster C $(\alpha=.87)$ and Cluster D $(\alpha=.86)$.

Psychological distress. The Brief Symptom Inventory (BSI) ${ }^{20}$ is a distress measure containing 53 items. Respondents rate how much discomfort they had experienced with certain problems in the past month. The scale produces scores on 9 symptom dimensions as well as 3 global indices. Of the global indices, the General Severity Index (GSI) was used here, indicating the current perceived distress level. The scale ranges from o to 4 , with higher scores indicating a higher level of distress. In this study, the GSI attained very good internal reliability $(\alpha=.96)$ and stability across time $(r=.87, p<.001)$.

Hostile emotions. In order to measure the behavioural manifestation of hostile emotions, we used the Anger Idioms Scale (AIS). ${ }^{21}$ This scale has 11 items, and it ranges from o to 40, higher scores indicating more hostile emotions. In this study, the alpha of the scale increased from 0.65 to 0.75 when item 11 was removed, and test-retest stability was acceptable $(r=.52, p<.01)$. Therefore, a sum score was calculated on the basis of the first 10 items of the AIs.

Culture shock. The Culture Shock Questionnaire (CSQ)22 was used in this study. It consists of 12 items ranging from 1 to 4 , with higher scores indicating a higher level of cultural shock. 
The internal consistency of CSQ found in our study was satisfactory $(\alpha=.77)$

\section{Sources of Support}

Family functioning. The McMaster Family Assessment Device $(\mathrm{FAD})^{23}$ is a 60 -item questionnaire reflecting 6 dimensions of family functioning. In addition, this tool includes 12 items that can assess the family's general functioning with no need to use all items. ${ }^{24}$ The scale ranges from 1 to 4 , with higher scores representing lower family functioning. In our sample, this scale had a Cronbach's alpha $=.60$, and testretest correlation $r=.06(n s)$.

Perceived social support. We used the 12-item Multidimensional Scale of Perceived Social Support (MSPss) ${ }^{25}$ to measure the degree of support from family, friends, and a significant other. The scale ranges from 1 to 7 , with higher scores indicating more support. In the current study, Cronbach's a coefficients and stability correlations for significant others, family, and friends subscales were $.86(r=.63, p<.001), .80(r=.88$, $p<.001)$ and $.82(r=.79, p<.001)$, respectively. The overall score also obtained high internal consistency $(\alpha=.90)$ and test-retest reliability $(r=.84, p<.001)$.

\section{Statistical Analysis}

Descriptive statistics were used using sPss 17.0 software. Scores for each questionnaire were calculated, provided the participant answered at least $75 \%$ of items. Regression analyses were conducted to determine factors predicting quality of life.

\section{Results}

Stages 1 and 2

\section{Pre-Migration Traumatic Events}

Table 2 presents traumatic events that had been encountered by the respondents themselves before arriving to Israel. The majority of the respondents had suffered severe traumatic events including torture, forced labour, forced separation from family, lack of food or water, lack of shelter, and burning of houses. Women reported significantly fewer traumatic events than men; however, they were significantly more likely to experience rape (14\% of female respondents were raped and $20 \%$ sexually harassed, compared with $2 \%$ of male respondents detailing experiences of rape and $3 \%$ experiencing sexual harassment). No significant difference was found, in the number of events, between those with and without refugee status, but asylum-seekers holding a temporary A2(5)A visa were less likely to experience forced hiding, physical injury due to violence, and kidnapping. It may be that the first waves of Darfuris arriving in Israel came from Egypt after escaping violence in Sudan and Egypt,
Table 2. Pre-migration traumatic events

\begin{tabular}{|c|c|c|c|c|c|}
\hline & $\begin{array}{l}\text { Male } \\
(N= \\
276)\end{array}$ & $\begin{array}{l}\text { Female } \\
(N=64)\end{array}$ & $\begin{array}{l}\text { Has a } \\
\text { visa } \\
(\mathrm{N}= \\
58)\end{array}$ & $\begin{array}{l}\text { No visa } \\
(N= \\
282)\end{array}$ & $\begin{array}{l}\text { Total } \\
(N= \\
340)\end{array}$ \\
\hline Torture & $66 \% * *$ & $46 \% * *$ & $72 \%$ & $60 \%$ & $62 \%$ \\
\hline Imprisonment & $60 \%$ & $55 \%$ & $68 \%$ & $56 \%$ & $58 \%$ \\
\hline $\begin{array}{l}\text { Lack of food and } \\
\text { water }\end{array}$ & $65 \%$ & $67 \%$ & $70 \%$ & $64 \%$ & $65 \%$ \\
\hline Forced to hide & $55 \% *$ & $38 \% *$ & $72 \% * *$ & $48 \% * *$ & $52 \%$ \\
\hline Physical assault & $72 \% * *$ & $29 \% * *$ & $70 \%$ & $64 \%$ & $65 \%$ \\
\hline $\begin{array}{l}\text { Assault with a } \\
\text { weapon }\end{array}$ & $62 \% * *$ & $41 \% * *$ & $59 \%$ & $59 \%$ & $59 \%$ \\
\hline $\begin{array}{l}\text { Forced separation } \\
\text { from family }\end{array}$ & $67 \% *$ & $50 \% *$ & $75 \%$ & $61 \%$ & $64 \%$ \\
\hline $\begin{array}{l}\text { Confiscation or } \\
\text { destruction } \\
\text { of personal } \\
\text { property }\end{array}$ & $86 \% * *$ & $66 \% \%^{* *}$ & $75 \%$ & $84 \%$ & $83 \%$ \\
\hline $\begin{array}{l}\text { Combat situation/ } \\
\text { exposure to } \\
\text { war zone }\end{array}$ & $72 \%$ & $65 \%$ & $64 \%$ & $73 \%$ & $71 \%$ \\
\hline Lack of shelter & $78 \%$ & $73 \%$ & $72 \%$ & $79 \%$ & $78 \%$ \\
\hline $\begin{array}{l}\text { Serious physical } \\
\text { injury due to } \\
\text { violence }\end{array}$ & $20 \%$ & $22 \%$ & $33 \% *$ & $18 \% *$ & $20 \%$ \\
\hline $\begin{array}{l}\text { Serious illness } \\
\text { without access } \\
\text { to medical } \\
\text { care }\end{array}$ & $12 \%^{a}$ & $2 \% \mathrm{a}$ & $11 \%^{a}$ & $10 \%^{a}$ & $10 \%$ \\
\hline $\begin{array}{c}\text { Disappearance/ } \\
\text { kidnapping }\end{array}$ & $18 \%$ & $16 \%$ & $31 \% * *$ & $14 \%^{* *}$ & $17 \%$ \\
\hline $\begin{array}{l}\text { Slavery or forced } \\
\text { labour }\end{array}$ & $62 \% *$ & $45 \% *$ & $60 \%$ & $59 \%$ & $59 \%$ \\
\hline Raped & $2 \%^{a}$ & $14 \%^{a}$ & $10 \%{ }^{a}$ & $3 \%^{a}$ & $4 \%$ \\
\hline $\begin{array}{l}\text { Sexual harass- } \\
\text { ment }\end{array}$ & $3 \%{ }^{a}$ & $20 \%{ }^{a}$ & $11 \%{ }^{a}$ & $5 \%$ a & $6 \%$ \\
\hline $\begin{array}{c}\text { Thrown from } \\
\text { a moving } \\
\text { vehicle }\end{array}$ & $15 \%$ & $8 \%$ & $10 \%$ & $14 \%$ & $13 \%$ \\
\hline $\begin{array}{l}\text { Shot by soldiers/ } \\
\text { security } \\
\text { guards/ } \\
\text { janjaweed }\end{array}$ & $68 \%$ & $57 \%$ & $63 \%$ & $67 \%$ & $66 \%$ \\
\hline House burned & $74 \%$ & $65 \%$ & $69 \%$ & $73 \%$ & $72 \%$ \\
\hline $\begin{array}{l}\text { Serious injury, } \\
\text { harm, or death } \\
\text { you caused to } \\
\text { someone else }\end{array}$ & $4 \%^{a}$ & $10 \%{ }^{\mathrm{a}}$ & $9 \%^{a}$ & $3 \%^{a}$ & $5 \%$ \\
\hline Mean \& SD ${ }^{\mathrm{b}}$ & $8.8(4.5)^{* *}$ & $\begin{array}{l}6.4 \\
(5.2)^{* *}\end{array}$ & $\begin{array}{l}9.2 \\
(5.5)\end{array}$ & $8.1(4.5)$ & $8.3(4.7)$ \\
\hline
\end{tabular}

Expected cell frequencies too low to compute chi-squared test

$b_{1}$ to 21 , higher scores indicating more events 
while the later waves came straight to Israel, using Egypt as a transit route, spending insignificant periods of time in that country, and thus experienced less violence.

\section{Stage 3}

\section{Living Conditions in Israel}

The majority of the respondents (98\%) lived in an urban area in Israel, either in Tel Aviv (69\%) or in Eilat (19\%), were never arrested by the police (96\%), never consumed beer $(65 \%)$ and were members of a civil organization (85\%) (not shown in the table due to small variance). In other words, although the refugees are often viewed in the public eye as likely to be engaged in criminal activities and the abuse of alcohol, the data show that they live normative lives and are socially active (see table 3).

The living conditions in Israel were not easy: the majority had relatively low economic status (mean 1.9, on a scale for 1-6). Women (mostly married and living in families supported by two salaries) and those with refugee status were significantly more likely to have a higher sEs. The majority $(61 \%)$ had no health insurance, as they can only access private health insurance. Recognized refugees were significantly more likely to hold health insurance $(82 \%)$ as they are entitled to National Security insurance and access to public health. Thus, not surprisingly, $41 \%$ of the respondents turn to a voluntary organization (Physicians for Human Rights clinic) in order to receive medical care. Of the respondents, $56 \%$ had a full-time job, and those with refugee status were more likely (66\%) to hold such a job. Men were significantly more likely than women to work in hotels and construction, and women were more likely to work in housekeeping. The majority (53\%) sent money to relatives overseas.

Most respondents had refugee friends but no Israeli friends, with men more likely to have friends than women. They tended not to be satisfied with their decision to leave Sudan (mean $=2$, on a scale of 1 to 5 ), but women and those with refugee status reported a higher level of satisfaction. However, the respondents tended to be satisfied in coming to Israel (mean $=3.5$, on a scale of $1-5)$. The respondents were not likely to master Hebrew (mean $=1.6$, on a scale from 1 to 4 ), and to present a medium level of perceived discrimination (mean $=2.3$ on a scale 1 to 4 ), with women presenting a higher level of discrimination.

\section{Living Difficulties in Israel}

Respondents had experienced many difficulties in Israel in almost all areas: worries about family members at home, access to medical care, fears of deportation, work conditions and discrimination (mean $=13.8$ difficulties on a scale from 1 to 24 ) (see table 4 ).
Women were significantly more likely to experience difficulties, including discrimination, no permission to work, not finding jobs, conflict with immigration authorities, poor access to medical care, poverty, loneliness, and separation $($ mean $=17.6$ difficulties among women and 13 among men). Similarly, asylum-seekers were also more likely to report difficulties as compared to their recognized refugee counterparts, including no permission to work, fears of being sent home, and poor access to medical care (mean $=14.2$ difficulties with no visa, and 12.2 with a visa).

\section{Psychological, Familial, and Social State}

The participants reported a low level of psychological symptoms, as measured by the BsI scale (mean $=0.7$, on a scale for $0-4$ ) (see table 5). Women tended to present more psychological symptoms. With respect to PTSD, 30\% of the respondents suffered from this syndrome, with women significantly more likely to have a diagnosis of PTSD (55\% of women, as compared with $26 \%$ of men). This is interesting, because women suffered less traumatic events at preimmigration stage. However, they were more likely to have experienced rape and sexual harassment-dreadful events that might lead to PTSD. In addition, refugees were also more likely to have a diagnosis of PTSD than asylum-seekers ( $48 \%$ of refugees, compared with $27 \%$ of asylum-seekers). This figure corresponds to their greater exposure to traumatic events. It may also be that refugees, who are already settled down and have gained means of survival, have begun confronting their traumas while asylum-seekers were still struggling to survive.

In terms of familial relationships, applicable to those who have family members in Israel, the respondents presented an average level of family functioning (mean $=2.4$ on a scale for 1 to 4), with women showing slightly lower level of family functioning. With respect to social support, the participants presented a moderate level of support (mean $=4.6$ on a scale from 1 to 7 ), with women having significantly higher level of support (mean $=5.2$, as compared with 4.4); and asylum-seekers reporting a slightly higher support (mean $=4.7$, as compared with 4.1). In terms of cultural culture shock, respondents presented a low to moderate level of shock (mean $=2.5$ on a scale from 1 to 4 ), with women presenting a higher level of shock. In addition, the refugees tended to present low to moderate level of anger, with women presenting a slightly higher level of anger.

Finally, the respondents reported a moderate to high level of quality of life with respect to their physical health, psychological health, and social relations (means around 14 on a scale from 4 to 20). However, with respect to the environment, the score was lower $($ mean $=11.1)$, reflecting the hard living conditions of the participants in Israel in 
Table 3. Living conditions in Israel (Mean, SD, \%)

\begin{tabular}{|c|c|c|c|c|c|}
\hline & $\begin{array}{c}\text { Male } \\
(N=276)\end{array}$ & $\begin{array}{l}\text { Female } \\
(N=64)\end{array}$ & $\begin{array}{c}\text { Has a visa } \\
(N=58)\end{array}$ & $\begin{array}{l}\text { No visa } \\
(N=282)\end{array}$ & $\begin{array}{c}\text { Total } \\
(N=340)\end{array}$ \\
\hline Monthly income in dollars & $1005(403)^{* *}$ & $830(632)^{* *}$ & $1190(405)^{* *}$ & $920(461)^{* *}$ & $971(461)$ \\
\hline Economic status $^{a}$ & $1.8(0.9)^{* *}$ & $2.3(1.1)^{* *}$ & $2.2(1.3)^{*}$ & $1.9(0.9)^{*}$ & $1.9(1.0)$ \\
\hline Number of refugee friends & $4.0(6.2)^{* *}$ & $1.6(1.9)^{* *}$ & $4.9(7.8)$ & $3.2(4.9)$ & $3.5(5.7)$ \\
\hline Number of Israeli friends & $0.9(1.4)$ & $0.7(1.5)$ & $1.1(1.2)$ & $0.8(1.4)$ & $0.8(1.4)$ \\
\hline Satisfaction from leaving Sudan ${ }^{b}$ & $1.8(1.2)^{* *}$ & $2.9(1.3)^{* *}$ & $2.6(1.5)^{* *}$ & $1.9(1.2)^{* *}$ & $2.0(1.3)$ \\
\hline Satisfaction from coming to Israel $^{b}$ & $3.6(1.0)^{* *}$ & $3.1(1.0)^{* *}$ & $3.5(1.1)$ & $3.5(1.0)$ & $3.5(1.0)$ \\
\hline Contact with family overseas ${ }^{c}$ & $3.0(1.3)$ & $2.9(1.2)$ & $3.1(1.2)$ & $2.9(1.2)$ & $2.9(1.2)$ \\
\hline \multicolumn{6}{|l|}{ Health insurance } \\
\hline Yes & $38 \%$ & $39 \%$ & $82 \% * *$ & $29 \% * *$ & $39 \%$ \\
\hline No & $62 \%$ & $61 \%$ & $18 \% \%^{* *}$ & $71 \%{ }^{* *}$ & $61 \%$ \\
\hline \multicolumn{6}{|l|}{ Type of medical help being used } \\
\hline Physicians for Human Rights clinic & $35 \% \%^{* *}$ & $69 \% * *$ & $26 \% * *$ & $44 \% * *$ & $41 \%$ \\
\hline Public medical clinic & $22 \% * *$ & $14 \% \%^{* *}$ & $52 \% * *$ & $15 \% * *$ & $20 \%$ \\
\hline Hospitals & $12 \% * *$ & $5 \% * *$ & $8 \% * *$ & $11 \% * *$ & $11 \%$ \\
\hline Other & $13 \% * *$ & $5 \% * *$ & $12 \% * *$ & $11 \% * *$ & $12 \%$ \\
\hline Never used medical help & $18 \% * *$ & $7 \% * *$ & $2 \% * *$ & $19 \% * *$ & $16 \%$ \\
\hline \multicolumn{6}{|l|}{ Occupational status } \\
\hline Full-time job & $56 \%{ }^{* *}$ & $56 \% * *$ & $66 \% *$ & $54 \% *$ & $56 \%$ \\
\hline Part-time job & $17 \% * *$ & $14 \%^{* *}$ & $22 \% *$ & $16 \% *$ & $17 \%$ \\
\hline Daily worker & $18 \%{ }^{* *}$ & $1 \% * *$ & $7 \% *$ & $15 \% *$ & $14 \%$ \\
\hline Unemployed & $9 \% * *$ & $29 \% * *$ & $5 \% *$ & $15 \% *$ & $13 \%$ \\
\hline \multicolumn{6}{|l|}{ Workplace } \\
\hline Hospitality & $34 \% * *$ & $25 \% * *$ & $25 \% \%^{* *}$ & $35 \% * *$ & $32 \%$ \\
\hline Construction & $22 \% * *$ & $0 \% * *$ & $8 \% * *$ & $20 \% * *$ & $18 \%$ \\
\hline Housekeeping & $10 \% * *$ & $39 \% * *$ & $35 \% * *$ & $10 \% * *$ & $16 \%$ \\
\hline Other & $26 \% * *$ & $9 \% * *$ & $24 \% * *$ & $23 \% * *$ & $23 \%$ \\
\hline Unemployed & $8 \% * *$ & $27 \% \%^{* *}$ & $8 \% * *$ & $12 \% * *$ & $11 \%$ \\
\hline \multicolumn{6}{|l|}{ Type of employment ${ }^{f}$} \\
\hline Contracted & $17 \% *$ & $7 \% *$ & $40 \% * *$ & $10 \% * *$ & $16 \%$ \\
\hline Employment agency & $66 \% *$ & $86 \% *$ & $58 \% * *$ & $71 \% * *$ & $68 \%$ \\
\hline Unregistered employment & $17 \% *$ & $7 \% *$ & $2 \% * *$ & $19 \% * *$ & $16 \%$ \\
\hline \multicolumn{6}{|l|}{ Being paid in last 3 months ${ }^{f}$} \\
\hline Always been paid & $76 \%$ & $75 \%$ & $85 \%$ & $74 \%$ & $76 \%$ \\
\hline Not been paid & $24 \%$ & $25 \%$ & $15 \%$ & $26 \%$ & $24 \%$ \\
\hline \multicolumn{6}{|l|}{ Social Benefits $^{f}$} \\
\hline \multicolumn{6}{|l|}{ Bus fare } \\
\hline Yes & & $71 \%$ & $82 \% * *$ & & \\
\hline No & $(N=276)$ & $29 \%$ & $18 \% * *$ & $(N=282)$ & $(N=340)$ \\
\hline \multicolumn{6}{|l|}{ Payment for extra hours } \\
\hline Yes & $49 \%$ & $54 \%$ & $56 \%$ & $48 \%$ & $50 \%$ \\
\hline No & $51 \%$ & $46 \%$ & $44 \%$ & $52 \%$ & $50 \%$ \\
\hline \multicolumn{6}{|l|}{ Holidays } \\
\hline Yes & $27 \% * *$ & $54 \%^{* *}$ & $55 \% * *$ & $26 \% * *$ & $32 \%$ \\
\hline No & $73 \% * *$ & $46 \% * *$ & $45 \% * *$ & $74 \% * *$ & $68 \%$ \\
\hline \multicolumn{6}{|l|}{ Medical insurance } \\
\hline Yes & $40 \%$ & $56 \%$ & $80 \% * *$ & $33 \% * *$ & $43 \%$ \\
\hline No & $60 \%$ & $44 \%$ & $20 \% * *$ & $67 \% * *$ & $57 \%$ \\
\hline
\end{tabular}

(C) Vered Slonim-Nevo, Shirley Regev and Yiftach Millo, 2015. This open-access work is licensed under a Creative Commons AttributionNonCommercial 4.0 International License, which permits use, reproduction and distribution in any medium for non-commercial purposes, provided the original author(s) are credited and the original publication in Refuge: Canada's Journal on Refugees is cited. 
Table 3 (continued)

\begin{tabular}{|c|c|c|c|c|c|}
\hline & $\begin{array}{c}\text { Male } \\
(N=276)\end{array}$ & $\begin{array}{l}\text { Female } \\
(N=64)\end{array}$ & $\begin{array}{c}\text { Has a visa } \\
(N=58)\end{array}$ & $\begin{array}{l}\text { No visa } \\
(N=282)\end{array}$ & $\begin{array}{c}\text { Total } \\
(N=340)\end{array}$ \\
\hline \multicolumn{6}{|l|}{ Compensation 9} \\
\hline Yes & $9 \%$ & $9 \%$ & $27 \%$ & $5 \%$ & $9 \%$ \\
\hline No & $91 \%$ & $91 \%$ & $73 \%$ & $95 \%$ & $91 \%$ \\
\hline \multicolumn{6}{|l|}{ Pensiong } \\
\hline Yes & $7 \%$ & $3 \%$ & $29 \%$ & $1 \%$ & $6 \%$ \\
\hline No & $93 \%$ & $97 \%$ & $71 \%$ & $99 \%$ & $94 \%$ \\
\hline \multicolumn{6}{|l|}{ Social security ${ }^{g}$} \\
\hline Yes & $12 \%$ & $21 \%$ & $49 \% * *$ & $5 \% * *$ & $14 \%$ \\
\hline No & $88 \%$ & $79 \%$ & $51 \% * *$ & $95 \% * *$ & $86 \%$ \\
\hline \multicolumn{6}{|l|}{ Send money overseas } \\
\hline Yes & $60 \% * *$ & $19 \%^{* *}$ & $48 \%$ & $53 \%$ & $53 \%$ \\
\hline No & $40 \% * *$ & $81 \% * *$ & $52 \%$ & $47 \%$ & $47 \%$ \\
\hline Proficiency in Hebrew ${ }^{d}$ & $1.7(0.6)$ & $1.6(0.5)$ & $1.9(0.7)^{* *}$ & $1.6(0.6)^{* *}$ & $1.6(0.6)$ \\
\hline Perceived Discrimination ${ }^{\mathrm{e}}$ & $2.2(1.0)^{* *}$ & $2.9(0.9)^{* *}$ & $2.4(1.0)$ & $2.3(1.0)$ & $2.3(1.0)$ \\
\hline \multicolumn{6}{|c|}{ Where see oneself settled in 5 years 9} \\
\hline In Israel & $5 \%$ & $9 \%$ & $12 \%$ & $4 \%$ & $6 \%$ \\
\hline In Darfur, only if there is peace & $59 \%$ & $66 \%$ & $57 \%$ & $61 \%$ & $60 \%$ \\
\hline In Darfur, anyway & $4 \%$ & $8 \%$ & $4 \%$ & $5 \%$ & $5 \%$ \\
\hline Resettled in another country & $15 \%$ & $11 \%$ & $18 \%$ & $14 \%$ & $14 \%$ \\
\hline Don't know & $17 \%$ & $6 \%$ & $9 \%$ & $16 \%$ & $15 \%$ \\
\hline
\end{tabular}

a1 to 6 , higher scores indicating better economic status

b1 to 5 , higher scores indicating greater satisfaction

${ }^{c} 1$ to 7 , higher scores indicating higher frequency

$\mathrm{d}_{1}$ to 4 , higher scores indicating better Hebrew proficiency

e 1 to 4 , higher scores indicating worse perceived discrimination

${ }^{f}$ For those who are employed

gIn some cells, expected frequencies were too low to compute chi-squared test

${ }^{*} p<.05 .{ }^{* *} p<.01$

terms of financial resources, housing, and health. Women reported a lower level of physical and psychological quality of life, a finding that is in accordance with their overall lower level of socio-psychological state. Also, recognized refugees were more likely to report a lower level of physical health and social relations.

\section{Predictors of Quality of Life}

To model the predictors of quality of life, we conducted a series of hierarchical regressions. These analyses examined the relative contributions of gender, legal status, perceived discrimination, PTSD diagnosis, and post-migration living difficulties on the 4 domains of quality of life described above. For each domain outcome: gender and legal status were entered at step 1; post-migration living difficulties, PTSD diagnosis, and perceived discrimination were entered at step 2 (see table 6). The predictors were chosen on the basis of previous bi-variant analyses suggesting that they are related to the dependent variable. In addition, these predictors come from the 4 domains of the ecological systems theory: gender and PTSD's diagnosis belong to the micro-system, perceived discrimination belongs to the meso-system, and living difficulties and legal status belong to the exo-system as well as to the macro-system.

Physical health. At step 1, a model containing gender and legal status significantly predicted physical health: $F(2,251)$ $=8.43, p<0.001$, accounting for $6.3 \%$ of the variance. Both gender and legal status were important factors, with males and visa holders reporting better quality of life with regard to physical health. When PTSD diagnosis, perceived discrimination, and living difficulties were added at step 2, a further $31.6 \%$ of the variance was accounted for: $F_{c h}(3,248)=42.01$, $p<0.001$, with PTSD diagnosis and perceived discrimination making a significant and unique contribution. Participants who did not meet the criteria for PTSD and those who had lower levels of perceived discrimination also reported better quality of physical health. Gender was no longer significant,

(C) Vered Slonim-Nevo, Shirley Regev and Yiftach Millo, 2015. This open-access work is licensed under a Creative Commons AttributionNonCommercial 4.0 International License, which permits use, reproduction and distribution in any medium for non-commercial purposes, provided the original author(s) are credited and the original publication in Refuge: Canada's Journal on Refugees is cited. 
Table 4. Post-migration living difficulties (serious/very serious problems)

\begin{tabular}{|c|c|c|c|c|c|}
\hline & $\begin{array}{l}\text { Male } \\
(N= \\
276)\end{array}$ & $\begin{array}{l}\text { Fe- } \\
\text { male } \\
(N= \\
64)\end{array}$ & $\begin{array}{l}\text { Has a } \\
\text { visa } \\
(N= \\
58)\end{array}$ & $\begin{array}{l}\text { No } \\
\text { visa } \\
(N= \\
282)\end{array}$ & $\begin{array}{l}\text { Total } \\
(N= \\
340)\end{array}$ \\
\hline \multicolumn{6}{|l|}{ Communication } \\
\hline difficulties & $15 \%^{* *}$ & $49 \% * *$ & $20 \%$ & $22 \%$ & $21 \%$ \\
\hline Discrimination & $62 \% * *$ & $85 \% * *$ & $66 \%$ & $66 \%$ & $66 \%$ \\
\hline Separation from family & $75 \%$ & $82 \%$ & $73 \%$ & $77 \%$ & $76 \%$ \\
\hline \multicolumn{6}{|l|}{ Worries about family } \\
\hline back at home & $91 \%$ & $97 \%$ & $89 \%$ & $93 \%$ & $92 \%$ \\
\hline \multicolumn{6}{|l|}{ Unable to return home } \\
\hline in emergency & $85 \%$ & $92 \%$ & $80 \%$ & $87 \%$ & $86 \%$ \\
\hline No permission to work & $55 \% * *$ & $78 \% * *$ & $40 \% * *$ & $63 \% * *$ & $59 \%$ \\
\hline Not able to find work & $49 \% * *$ & $79 \% * *$ & $42 \%$ & $56 \%$ & $54 \%$ \\
\hline Bad job conditions & $53 \% * *$ & $82 \% * *$ & $54 \%$ & $60 \%$ & $59 \%$ \\
\hline Being in detention & $29 \% * *$ & $74 \% * *$ & $40 \%$ & $37 \%$ & $37 \%$ \\
\hline \multicolumn{6}{|l|}{ Interviews by } \\
\hline immigration & $16 \% * *$ & $58 \% * *$ & $31 \%$ & $22 \%$ & $24 \%$ \\
\hline \multicolumn{6}{|l|}{ Delays in processing } \\
\hline visa application & $27 \% * *$ & $61 \% * *$ & $38 \%$ & $32 \%$ & $34 \%$ \\
\hline $\begin{array}{l}\text { Conflict with immigra- } \\
\text { tion officials }\end{array}$ & $18 \% * *$ & $62 \% * *$ & $33 \%$ & $25 \%$ & $26 \%$ \\
\hline \multicolumn{6}{|l|}{ Fears of being sent } \\
\hline home & $81 \%$ & $80 \%$ & $67 \% * *$ & $84 \% * *$ & $81 \%$ \\
\hline $\begin{array}{l}\text { Worries about not get- } \\
\text { ting medical care }\end{array}$ & $64 \% *$ & $77 \% *$ & $46 \% * *$ & $71 \% \%^{* *}$ & $67 \%$ \\
\hline $\begin{array}{l}\text { Poor access to emer- } \\
\text { gency medical care }\end{array}$ & $58 \% * *$ & $80 \% * *$ & $52 \%$ & $64 \%$ & $62 \%$ \\
\hline $\begin{array}{l}\text { Poor access to long- } \\
\text { term medical care }\end{array}$ & $71 \%$ & $74 \%$ & $60 \% *$ & $74 \% *$ & $72 \%$ \\
\hline \multicolumn{6}{|l|}{ Poor access to dentistry } \\
\hline care & $59 \% *$ & $64 \% *$ & $54 \%$ & $63 \%$ & $62 \%$ \\
\hline \multicolumn{6}{|l|}{ Poor access to counsel- } \\
\hline ling services & $60 \%$ & $65 \%$ & $33 \% * *$ & $67 \% * *$ & $61 \%$ \\
\hline \multicolumn{6}{|l|}{ Little government help } \\
\hline with welfare & $58 \%$ & $70 \%$ & $46 \% *$ & $63 \% *$ & $60 \%$ \\
\hline \multicolumn{6}{|l|}{ Little help with welfare } \\
\hline from charities & $58 \%$ & $71 \%$ & $51 \% *$ & $63 \%$ & $61 \%$ \\
\hline Poverty & $75 \% *$ & $87 \% *$ & $71 \%$ & $79 \%$ & $77 \%$ \\
\hline \multicolumn{6}{|l|}{ Loneliness and } \\
\hline boredom & $63 \% * *$ & $85 \% * *$ & $71 \%$ & $67 \%$ & $68 \%$ \\
\hline Isolation & $60 \% * *$ & $82 \% * *$ & $74 \%$ & $62 \%$ & $64 \%$ \\
\hline \multicolumn{6}{|l|}{ Poor access to the } \\
\hline foods you like & $32 \% * *$ & $68 \% * *$ & $35 \%$ & $40 \%$ & $39 \%$ \\
\hline Mean \& $S D^{b}$ & $\begin{array}{l}13.0 \\
(5.3)^{* *}\end{array}$ & $\begin{array}{l}17.6 \\
(5.7)^{* *}\end{array}$ & $\begin{array}{l}12.2 \\
(6.2)^{*}\end{array}$ & $\begin{array}{l}14.2 \\
(5.5)^{*}\end{array}$ & $\begin{array}{l}13.8 \\
(5.7)\end{array}$ \\
\hline
\end{tabular}

Expected cell frequencies too low

$b_{1}$ to 24 , higher scores indicating more problems

${ }^{*} p<.05 .{ }^{* *} p<.01$

Table 5. Psychological, familial, and social state (Mean, SD, \%)

\begin{tabular}{|c|c|c|c|c|c|}
\hline & $\begin{array}{l}\text { Male } \\
(N= \\
276)\end{array}$ & $\begin{array}{l}\text { Female } \\
(N=64)\end{array}$ & $\begin{array}{l}\text { Has a } \\
\text { visa } \\
(N=58)\end{array}$ & $\begin{array}{l}\text { No visa } \\
(N= \\
282)\end{array}$ & $\begin{array}{l}\text { Total } \\
(N= \\
340)\end{array}$ \\
\hline BSI ${ }^{\mathrm{a}}$ & & & & & 0.7 \\
\hline Somatization & & & & & $(0.7)$ \\
\hline Obsessive- & & & & & 0.4 \\
\hline compulsive & & & & & $(0.6)$ \\
\hline Interpersonal & & & & & 0.8 \\
\hline sensitivity & & & & & $(0.9)$ \\
\hline Depression & & & & & 0.9 \\
\hline Anxiety & & & & & $(1.0)$ \\
\hline Hostility & $0.7(0.7)^{*}$ & & & & 1.0 \\
\hline Phobic anxiety & $0.3(0.6)^{*}$ & & & & $(0.9)$ \\
\hline Paranoid & $0.8(0.9)$ & $0.9(0.6)^{*}$ & $0.8(0.7)$ & $0.7(0.7)$ & 0.7 \\
\hline ideation & $0.9(1.0)$ & $0.5(0.7)^{*}$ & $0.4(0.6)$ & $0.4(0.6)$ & $(0.8)$ \\
\hline \multirow[t]{8}{*}{ Psychoticism } & $1.0(0.9)$ & $1.0(0.8)$ & $1.0(1.0)$ & $0.8(1.0)$ & 0.4 \\
\hline & 0.6 & $1.1(1.0)$ & $1.1(1.0)$ & $0.9(1.0)$ & $(0.7)$ \\
\hline & $(0.8)^{* *}$ & $1.1(0.9)$ & $1.1(0.9)$ & $1.0(0.9)$ & 0.6 \\
\hline & $0.4(0.7)$ & $1.0(0.8)^{* *}$ & $0.8(0.8)$ & $0.7(0.8)$ & $(0.7)$ \\
\hline & 0.5 & $0.6(0.7)$ & $0.6(0.8)^{*}$ & $0.4(0.6)^{*}$ & 1.1 \\
\hline & $(0.7)^{* *}$ & $0.8(0.7)^{* *}$ & $0.6(0.7)$ & $0.6(0.7)$ & $(0.8)$ \\
\hline & $1.1(0.8)$ & $1.1(0.8)$ & $1.2(0.8)$ & $1.0(0.8)$ & 0.6 \\
\hline & $0.5(0.7)$ & $0.7(0.7)$ & $0.8(0.8)^{*}$ & $0.5(0.7)^{*}$ & $(0.7)$ \\
\hline WHOQOL- & & & 13.8 & 15.1 & 14.9 \\
\hline BREF ${ }^{b}$ & & & $(3.5)^{*}$ & $(3.0)^{*}$ & $(3.1)$ \\
\hline Physical health & 15.1 & 13.9 & 14.3 & 14.5 & 14.5 \\
\hline Psychological & $(3.2)^{* *}$ & $(2.6)^{* *}$ & (3.3) & (2.8) & $(2.8)$ \\
\hline health & 14.9 & 12.6 & 13.4 & 14.3 & 14.2 \\
\hline Social & $(2.5)^{* *}$ & $(3.4)^{* *}$ & $(3.4)^{*}$ & $(2.8)^{*}$ & $(3.0)$ \\
\hline relationships & $14.2(3.0)$ & $14.3(2.7)$ & 11.3 & 11.1 & 11.1 \\
\hline Environment & $11.1(2.3)$ & $11.3(8.2)$ & (3.1) & (4.3) & $(4.1)$ \\
\hline \multicolumn{6}{|l|}{ PTSD diagnosis } \\
\hline No & $74 \%^{* *}$ & $45 \% * *$ & $52 \% * *$ & $73 \% * *$ & $70 \%$ \\
\hline Yes & $26 \% * *$ & $55 \% * *$ & $48 \% * *$ & $27 \%^{* *}$ & $30 \%$ \\
\hline \multirow[t]{2}{*}{ FAD $^{C}$} & 2.4 & & & & 2.4 \\
\hline & $(0.1)^{* *}$ & $2.5(0.2)^{* *}$ & $2.4(0.1)$ & $2.4(0.1)$ & $(0.1)$ \\
\hline \multirow[t]{2}{*}{ MSPSS $^{d}$} & 4.4 & & 4.1 & 4.7 & 4.6 \\
\hline & $(1.1)^{* *}$ & $5.2(1.0)^{* *}$ & $(1.3)^{* *}$ & $(1.1)^{* *}$ & $(1.2)$ \\
\hline \multirow[t]{2}{*}{ Culture Shock } & 2.4 & & & & 2.5 \\
\hline & $(0.4)^{* *}$ & $2.7(0.4)^{* *}$ & $2.5(0.4)$ & $2.5(0.5)$ & $(0.4)$ \\
\hline Anger Idioms & 20.0 & 22.0 & 20.3 & 20.4 & 20.4 \\
\hline Scale $^{f}$ & $(4.2)^{* *}$ & $(4.4)^{* *}$ & $(4.4)$ & (4.3) & $(4.3)$ \\
\hline \multicolumn{6}{|c|}{ aBrief Symptom Inventory, o to 4, higher scores indicating worse psycho- } \\
\hline \multicolumn{6}{|c|}{$\mathrm{b}_{4}$ to 20 , higher scores indicating better quality of life } \\
\hline \multirow{2}{*}{\multicolumn{6}{|c|}{$\begin{array}{l}\text { 'Family Assessment Device, } 1 \text { to } 4 \text {, higher scores indicating worse family } \\
\text { functioning }\end{array}$}} \\
\hline & & & & & \\
\hline \multicolumn{6}{|c|}{ dMultidimensional Scale of Perceived Social Support, 1 to 7, higher scores } \\
\hline \multicolumn{6}{|c|}{ indicating better perceived social support } \\
\hline \multicolumn{6}{|c|}{$\mathrm{e}_{1}$ to 4 , higher scores indicating a higher level of culture shock } \\
\hline \multicolumn{6}{|c|}{$\begin{array}{l}\text { fo to } 40 \text {, higher scores indicating more hostile emotions } \\
{ }^{*} p<.05 .{ }^{* *} p<.01\end{array}$} \\
\hline
\end{tabular}

(C) Vered Slonim-Nevo, Shirley Regev and Yiftach Millo, 2015. This open-access work is licensed under a Creative Commons AttributionNonCommercial 4.0 International License, which permits use, reproduction and distribution in any medium for non-commercial purposes, provided the original author(s) are credited and the original publication in Refuge: Canada's Journal on Refugees is cited. 
Table 6. Hierarchical multiple linear regressions predicting physical health, psychological health, social relationship, and environment

\begin{tabular}{|c|c|c|c|c|}
\hline & \multicolumn{4}{|c|}{ Domains of quality of life } \\
\hline & Physical health & Psychological health & Social relationship & Environment \\
\hline \multicolumn{5}{|l|}{ Predictor } \\
\hline Step 1 & $\beta$ & $\beta$ & $\beta$ & $\beta$ \\
\hline Gender & $-.14^{*}$ & $-.23^{* * *}$ & .03 & -.08 \\
\hline Legal status & $.21^{* *}$ & .05 & .07 & -.07 \\
\hline \multicolumn{5}{|l|}{ Step 2} \\
\hline Gender & -.01 & -.10 & 11 & .05 \\
\hline Legal status & $.14^{* *}$ & -.00 & .02 & -.05 \\
\hline PTSD diagnosis & $-.40 * * *$ & $-.29 * * *$ & $-.27^{* * *}$ & .03 \\
\hline Perceived discrimination & $-.30 * * *$ & $-.38^{* * *}$ & $-.15^{*}$ & $-.24^{* * *}$ \\
\hline$\Delta R^{2}$ & $.316^{* * *}$ & $.308^{* * *}$ & $.117^{* * * *}$ & $.252^{* * *}$ \\
\hline$N$ & 254 & 251 & 254 & 254 \\
\hline
\end{tabular}

Gender: 0 = male, $1=$ female; Legal status: 0 = asylum seeker, 1 = refugee; PTSD: 0 = no PTSD, 1 = has PTSD; Perceived discrimination: higher scores indicating higher levels of perceived discrimination; Post-migration living difficulties: higher scores indicating more problems; Quality of life: higher scores indicating better quality of life.

${ }^{*} p<.05 ;{ }^{* *} p<.01 ;{ }^{* * *} p<.001$

but legal status was still important. The overall model was significant: $F(5,248)=30.23, p<0.001$, accounting for $37.9 \%$ of the variance in physical health scores.

Psychological health. At step 1, a model containing both gender and legal status significantly predicted psychological health: $F(2,248)=7.30, p<0.01$, accounting for $5.6 \%$ of the variance. Gender was the only significant variable, as males in this sample reported better quality of psychological health, compared with females. Inclusion of PTSD diagnosis, perceived discrimination, and living difficulties at step 2 produced a significant $30.8 \%$ increment in variance accounted for: $F_{c h}(3,245)=39.61, p<0.001$, with PTSD diagnosis and perceived discrimination making a significant and unique contribution. Participants who did not meet the criteria for PTSD and those who had lower levels of perceived discrimination also reported better quality of psychological health. Gender made a unique contribution only at $p=0.07$. The overall model was significant: $F(5,245)=28.05, p<0.001$, accounting for $36.4 \%$ of the variance in psychological health scores.

Social relationships. At Step 1, a model containing gender and age did not account for significant variance in predicting social relationships: $F(2,251)<1.00, F(2,251)<1.00$, explaining only $0.6 \%$ of the variance. At step 2, PTSD diagnosis, perceived discrimination and living difficulties were entered and the model accounted for an additional $11.7 \%$ of the variance:
$F_{c h}(3,248)=11.04, p<0.001$, with PTSD diagnosis and perceived discrimination making a significant and unique contribution. Participants who did not meet the criteria for PTSD and those who had lower levels of perceived discrimination reported better quality of social relationships. Gender also made a unique contribution at $p=0.07$. The overall model was significant: $F(5,248)=6.98, p<0.001$, accounting for $12.3 \%$ of the variance in social relationships scores.

Environmental factors. At step 1, a model containing gender and legal status did not account for significant variance in predicting environmental scores: $F(2,251)=1.6$, (ns), explaining only $1.2 \%$ of the variance. At step 2, PTSD diagnosis, perceived discrimination, and post-migration living difficulties were entered and the model accounted for an additional $25.2 \%$ of the variance: $F_{c h}(3,248)=28.27, p<0.001$. Perceived discrimination and living difficulties emerged as the only significant predictors. Participants with lower levels of perceived discrimination and fewer living difficulties reported better quality quality life in the domain of environment. The overall model was significant: $F(5,248)=17.78, p<0.001$, accounting for $26.4 \%$ of the variance in environment scores.

\section{Discussion}

In this study, we present a profile of Darfuri refugees and asylum-seekers in Israel according to 4 stages in the participants' journey and we analyze their quality of life according to 4 domains: physical health, psychological health, social

(C) Vered Slonim-Nevo, Shirley Regev and Yiftach Millo, 2015. This open-access work is licensed under a Creative Commons AttributionNonCommercial 4.0 International License, which permits use, reproduction and distribution in any medium for non-commercial purposes, provided the original author(s) are credited and the original publication in Refuge: Canada's Journal on Refugees is cited. 
relationship, and environmental factors, and tried to predict these domains using individual and social factors.

The first and second stages consider the period before and during the war and displacement, respectively. The vast majority of the participants experienced a high rate of severe pre-migration traumas in stages 1 and 2, including lack of shelter and food, being in combat, separation from family, exposure to slavery, imprisonment, and torture.

The high rates of trauma exposure found here are greater than those shown in a study among Sudanese and Eritrean refugees in Israel. ${ }^{26}$ This difference may be attributed to different migration periods: the report by Nakash et al. focused on traumatic events during transit to Israel via the Sinai desert, whereas our research referred to traumas experienced mostly before migration, presumably, in the war zone or in Khartoum. Indeed, the extant of war-related traumatic exposure in our study is consistent with that previously reported among Darfuri refugees ${ }^{27}$ and among other populations of displaced refugees. ${ }^{28}$

Women demonstrated fewer overall traumatic events but were at greater risk of experiencing sexual violence. This pattern is consistent with prior research of gender differences in reports of traumatic events. ${ }^{29}$ The overall levels of trauma reported by holders of temporary visas and those without it were similar, although the former group who arrived earlier did report more personal experiences of physical injury, disappearance, and being forced to hide.

The third stage examined living conditions and mental state throughout post-migration period. Despite the trauma, participants were able to manage regular daily life, as apparent from their high employment rates $(87 \%)$, which are above that reported among Darfuri refugees living in camps (21.9\%), ${ }^{30}$ and higher than the prevalence of $23.8 \%^{31}$ and $39.0 \%{ }^{32}$ for Sudanese refugees resettled in Australia and Canada, respectively.

There were no significant differences between refugees and asylum-seekers in age, marital status, levels of education, and residency in Sudan. The two groups also exhibited similar levels of culture shock and psychological distress. As expected, asylum-seekers had stayed in Israel for shorter lengths of time, but also reported shorter periods since departure, meaning that they had not been displaced in other countries for any significant periods, while those recognized as refugees did spend a significant period in Egypt before deciding to move across the border into Israel.

Recognized refugees had higher rates of PTSD than asylum-seekers. This finding is interesting, as the two groups did not differ in the number of pre-migration traumatic events that were experienced. The finding is also inconsistent with previous reports that show that individuals with less protective residency status are more vulnerable to PTSD. ${ }^{33}$
This discrepancy may result from the fact that the studies of Steel and colleagues compared temporary and permanent visas holders. In contrast, in our study all participants suffered from insecure residency, as Israeli asylum policy keeps changing and thus did not provide long-term security, even for those recognized as refugees. In addition, recognized refugees are less likely to struggle with daily financial survival in Israel, as compared with asylum-seekers. It may be that when the struggle to survive is lessened, psychological symptoms and PTSD are more likely to surface. Another explanation may be related to the period of residency in Egypt for the group of refugees, where they might have faced significant stressors that had not been reported in the pre-migration traumatic events. ${ }^{34}$ Another explanation involves variables that may serve as protective factors against PTSD: high levels of religiosity 35 and perceived social support, ${ }^{36}$ which were more pronounced in the group of asylum-seekers than among the refugees.

Women were significantly younger than men, mostly married with children, and had lower levels of education. Compared to men, women had more negative outcomes on most psychological measures: higher levels of perceived discrimination, greater psychological distress, increased prevalence of PTSD, poorer family functioning, higher levels of culture shock, and elevated hostile emotions. The finding that women display greater levels of PTSD compared with men is consistent with previous research suggesting sex differences in vulnerability to PTSD. ${ }^{37}$

The study also examined predictors of quality of life. The results revealed that perceived discrimination played a significant role in perceived quality of life, as participants with high levels of perceived discrimination reported reduced quality of life. PTSD diagnosis was also a strong predictor of quality of life: participants who met the criteria for PTSD were at greater risk for poor quality of life, even after taking gender and living difficulties into account. Gender made a unique contribution to the prediction of quality of life: women were more likely than men to suffer from poor quality of life. However, when PTSD diagnosis, perceived discrimination, and living difficulties were added to the model, gender was not longer a significant predictor of life quality measures. This suggests that gender differences in quality of life might be due to women's higher scores on PTSD, perceived discrimination, and living difficulties. Similarly, legal status also had a significant effect on quality of life, which was also reduced after statistically controlling for PTSD, perceived discrimination, and living difficulties. Finally, difficulties in post-migration living were the strongest predictor of quality of life in the environmental domain: fewer difficulties increased the quality of life with regard to the environment. 
The study has a number of limitations. The use of snowball sampling methods may have induced a selection bias and hindered our ability to generalize these findings. However, we believe that our sample is representative of the generality of Darfuris in Israel, based on the heterogeneity found in respondents' demographic characteristics and our use of several geographic locations and ethnic variety. Another limitation is the use of retrospective reports to assess exposure to traumatic events. Such measures are susceptible to recall bias due to memory deficiencies and retrospective interpretation and may hinder the reliability of our findings. Also, the participants may have tended to exaggerate when reporting on their conditions to rationalize a claim for refugee status. Finally, our study focused on a single refugee population, which limits the ability to generalize our findings to other groups of asylum-seekers living in Israel. ${ }^{8}$

In sum, the Darfuris in this study demonstrated high frequencies of pre-migration traumatic exposure and serious post-migration living difficulties. These stressors were accompanied by high prevalence of PTSD. Thus, these findings have important implications for governmental immigration policies and for social practitioners. For the Israeli government, temporary protected groups like the Sudanese asylum seekers should have access to RSD. Moreover, those matching the requirements set by the Refugee Convention 1951 should gain all its entitlements, including access to employment and health care. Counselling services need to be provided to women and men who are survivors of sexual and gender-based violence and those suffering from PTSD. A clear policy and a suitable legislation have to be developed by the Israeli government that is based on rights and entitlements rather than deterrence and exclusion. The constantly changing policies contribute to the levels of stress and insecurity of asylum-seekers and eventually lead to increased levels of vulnerability in a population with few rights but many needs. Many of the respondents are still in detention at the Hollot detention centre and are unable to continue with normal lives. It is the duty of the Israeli government to provide these survivors with psychological help and dignified life in security.

Vered Slonim-Nevo is a professor of social work at the Spitzer Department of Social Work, Ben Gurion University of the Negev. Her research areas include immigration, refugees and asylum-seekers, clinical counselling, families, and child welfare. The author may be contacted at slonim@bgu.ac.il.

Shirley Regev is a PhD graduate from the Department of Psychology at Ben-Gurion University. She is a research fellow at the School of Psychology, Queen's University Belfast. The author may be contacted at S.Dorchin-Regev@qub.ac.uk.
Yiftach Millo is an international consultant on refugee protection serving as field coordinator for HIAS SGBV affecting atrisk refugee populations in Chad, Kenya, South Africa, and Uganda. The author may be contacted at ymillo@gmail.com.

\section{Notes}

1 Susan M. Meffert and Charles R. Marmar, "Darfur Refugees in Cairo Mental Health and Interpersonal Conflict in the Aftermath of Genocide," Journal of Interpersonal Violence 2, no. 2 (2009): 1835-48; Kathrin Stoll and Phyllis Johnson, "Determinants of the Psychosocial Adjustment of Southern Sudanese Men," Journal of Refugee Studies 20, no. 4 (2007): 621-40.

2 Martin Timothy Rowe, The Experience of Protest: Masculinity and Agency among Sudanese Refugees in Cairo (Cairo: American University in Cairo Press, 2009).

3 "Israeli Law No. 5712-1952, Entry into Israel Law," 1952, http://www.refworld.org/docid/3ae6b4eco.html.

4 Population, Immigration and Borders Authority (PIBA), "Data on Foreigners in Israel: Summary for 2013," 2014, http://www.piba.gov.il/PublicationAndTender/ForeignWorkersStat/Documents/563343n8o.pdf.

5 Yaron Hadas, Nurit Hashimshony-Yaffe, and John Campbell, "Infiltrators' or Refugees? An Analysis of Israel's Policy towards African Asylum-Seekers.” International Migration 51, no. 4 (2013): 144-57.

6 Shira Lawrence, "Anti-Infiltration Bill Passes into Law," African Refugee Development Center (ARDC), 2014, http:// ardc-israel.org/en/article/anti-infiltration-bill-passes-law.

7 Ilan Lior, "The End of the Strike of the Refugees from Africa: More than 1000 Were Incarcerated," Haaretz, 1 December 2014, http://www.haaretz.co.il/news/education/1.2215381; Lior, “The Supreme Court Declared That Hollot Should Be Closed in 9o Days," Haaretz, 12 September 2014, http://www.haaretz.co.il/news/law/1.2438172; Lior, "The Government Ignores the Supreme Court Decision and Continues to Call Asylum Seekers to Hollot," Haaretz, 29 September 2014, http://www.haaretz.co.il/ news/education/.premium-1.2445354.

8 Yuval Goren, "Humanitarian Organization: More than 22 Refugees That Were Deported to Sudan Died This Year," 6 May 2013, http://www.nrg.co.il/online/1/ART2/477/197 .html.

9 Barak Ravid and Ilan Lior, "Court Invalidates Legislation Allowing Israel to Detain Migrants without Trial," Haaretz, 16 September 2014, http://www.haaretz.com/ news/diplomacy-defense/.premium-1.547311.

10 "In the Nick of Time, Knesset Passes Amended AntiInfiltration Law," i24 News, 9 December 2014, http:// www.i24news.tv/app.php/en/news/israel/politics/53858141209-israel-parliament-passes-new-law-against-illegalmigrants. 
11 Alastair Ager, "Video Lecture and Transcript: Responding to the Psychosocial Needs of Refuge," 2007, http://www. forcedmigration.org/rfgexp/pdfs/1_2.pdf.

12 Lord Clinton-Davis and Yohannes Fassil, "Health and Social Problems of Refugees," Social Science \& Medicine 35, no. 4 (1992): 507-13; Ora Nakash, Benjamin Langer, Maayan Nagar, Shahar Shoham, Ido Lurie, and Nadav Davidovitch, "Exposure to Traumatic Experiences among Asylum Seekers from Eritrea and Sudan during Migration to Israel," Journal of Immigrant and Minority Health 17, no. 4 (2014): $1280-6$.

13 Ibid., 11.

14 Ibid., 12; Paul Cambridge and Lucy Williams, "Approaches to Advocacy for Refugees and Asylum Seekers: A Development Case Study for a Local Support and Advice Service," Journal of Refugee Studies 17, no. 1 (2004): 97-113; and Katrine Fangen, "Humiliation Experienced by Somali Refugees in Norway," Journal of Refugee Studies 19, no. 1 (2006): 69-93.

15 Urie Bronfenbrenner, "Ecology of the Family as a Context for Human Development: Research Perspectives," Developmental Psychology 22, no. 6 (1986): 723.

16 Richard F. Mollica, Yael Caspi-Yavin, Paola Bollini, Toan Truong, Svang Tor, and James Lavelle, "The Harvard Trauma Questionnaire: Validating a Cross-Cultural Instrument for Measuring Torture, Trauma, and Posttraumatic Stress Disorder in Indochinese Refugees," Journal of Nervous and Mental Disease 18o, no. 2 (1992): 111-16.

17 Derrick Silove, Z. Steel, P. McGorry, and P. Mohan, "Trauma Exposure, Post-Migration Stressors, and Symptoms of Anxiety, Depression and Post-traumatic Stress in Tamil Asylum-Seekers: Comparison with Refugees and Immigrants," Acta Psychiatrica Scandinavica 97, no. 3 (1998): 175-181; and Zachary Steel, Derrick Silove, Kevin Bird, Patrick McGorry, and P. Mohan, "Pathways from War Trauma to Posttraumatic Stress Symptoms among Tamil Asylum Seekers, Refugees, and Immigrants," Journal of Traumatic Stress 12, no. 3 (1999): 421-35.

18 whOQOL Group, "Development of the World Health Organization WHOQOL-BREF Quality of Life Assessment," Psychological Medicine 28, no. 3 (1998): 551-8.

19 F. W. Weathers, B.T. Litz, D. Herman, J. Huska, and T. Keane, "The PTSD Checklist-Civilian Version (PCL-C)" (Boston, MA: National Center for PTSD, 1994).

20 Leonard R. Derogatis and Nick Melisaratos, "The Brief Symptom Inventory: An Introductory Report," Psychological Medicine 13, no. 03 (1983): 595-605.

21 Robert G. Malgady, Lloyd H. Rogler, and Dharma E. Cortés, "Cultural Expression of Psychiatric Symptoms: Idioms of Anger among Puerto Ricans," Psychological Assessment 8, no. 3 (1996): 265-8.

22 D.B. Mumford, "The Measurement of Culture Shock," Social Psychiatry and Psychiatric Epidemiology 33, no. 4 (1998): 149-54.
23 Nathan B. Epstein, Lawrence M. Baldwin, and Duane S. Bishop, "The McMaster Family Assessment Device," Journal of Marital and Family Therapy 9, no. 2 (1983): 171-80.

24 Ty A. Ridenour, James Daley, and Wendy Reich, "Factor Analyses of the Family Assessment Device," Family Process 38, no. 4 (1999): 497-510.

25 Gregory D. Zimet, Nancy W. Dahlem, Sara G. Zimet, and Gordon K. Farley, "The Multidimensional Scale of Perceived Social Support," Journal of Personality Assessment 52, no. 1 (1988): 30-41.

26 Robert G. Malgady, Lloyd H. Rogler, and Dharma E. Cortés, "Cultural Expression of Psychiatric Symptoms: Idioms of Anger among Puerto Ricans," Psychological Assessment 8, no. 3 (1996): 265-8.

27 Alia Badri, Rik Crutzen, and H. W. Van den Borne, "Exposures to War-Related Traumatic Events and Post-traumatic Stress Disorder Symptoms among Displaced Darfuri Female University Students: An Exploratory Study," BMC Public Health 12, no. 1 (2012): 603.

28 Kamaldeep Bhui, Abdisalama Abdi, Mahad Abdi, Stephen Pereira, Mohammed Dualeh, David Robertson, Ganesh Sathyamoorthy, and Hellena Ismail, "Traumatic Events, Migration Characteristics and Psychiatric Symptoms among Somali Refugees," Social Psychiatry and Psychiatric Epidemiology 38, no. 1 (2003): 35-43; and Sharon S. Tang and Steven H. Fox, "Traumatic Experiences and the Mental Health of Senegalese Refugees," Journal of Nervous and Mental Disease 189, no. 8 (2001): 507-12.

29 David F. Tolin and Edna B. Foa. "Sex Differences in Trauma and Posttraumatic Stress Disorder: A Quantitative Review of 25 Years of Research," Psychological Bulletin 132, no. 6 (2006): 959.

30 Andrew Rasmussen, Leanh Nguyen, John Wilkinson, Sikhumbuzo Vundla, Sumithra Raghavan, Kenneth E. Miller, and Allen S. Keller, "Rates and Impact of Trauma and Current Stressors among Darfuri Refugees in Eastern Chad," American Journal of Orthopsychiatry 80, no. 2 (2010): 227-36.

31 Robert Schweitzer, Fritha Melville, Zachary Steel, and Philippe Lacherez, "Trauma, Post-Migration Living Difficulties, and Social Support as Predictors of Psychological Adjustment in Resettled Sudanese Refugees," Australian and New Zealand Journal of Psychiatry 40, no. 2 (2006): 179-88.

32 Laura Simich, Hayley Hamilton, and B. Khamisa Baya, "Mental Distress, Economic Hardship and Expectations of Life in Canada among Sudanese Newcomers," Transcultural Psychiatry 43, no. 3 (2006): 418-44.

33 Angela Nickerson, Zachary Steel, Richard Bryant, Robert Brooks, and Derrick Silove, "Change in Visa Status amongst Mandaean Refugees: Relationship to Psychological Symptoms and Living Difficulties," Psychiatry Research 187, no. 1 (2011): 267-74; and Zachary Steel, Derrick Silove, Robert Brooks, Shakeh Momartin, Bushra Alzuhairi, and I. N. A. 
Susljik, "Impact of Immigration Detention and Temporary Protection on the Mental Health of Refugees," British Journal of Psychiatry 188, no. 1 (2006): 58-64.

34 Ibid., 30.

35 Jacob Bentley, Zeba Ahmad, and John Thoburn, "Religiosity and Posttraumatic Stress in a Sample of East African
Refugees," Mental Health, Religion \& Culture 17, no. 2 (2014): 185-95.

36 Ibid., 31.

37 Ibid., 29.

38 Ibid., 12

(C) Vered Slonim-Nevo, Shirley Regev and Yiftach Millo, 2015. This open-access work is licensed under a Creative Commons AttributionNonCommercial 4.0 International License, which permits use, reproduction and distribution in any medium for non-commercial purposes, provided the original author(s) are credited and the original publication in Refuge: Canada's Journal on Refugees is cited. 